\title{
TREATMENT OF POSTHERPETIC NEURALGIA WITH 5\% TOPICAL LIDOCAINE PLASTER - EXPERIENCE FROM A SMALL COUNTY HOSPITAL: CASE REPORT
}

\author{
Maša Kontić ${ }^{1}$, Višnja Vičić-Hudorović ${ }^{2}$ and Narcis Hudorović ${ }^{3}$ \\ ${ }^{1}$ Department of Anesthesiology and Resuscitation, Dr Ivo Pedišić General Hospital, Sisak; \\ ${ }^{2}$ Vrapče Nursing School; ${ }^{3}$ Department of Endo- and Vascular Surgery, University Department of Surgery, \\ Sestre milosrdnice University Hospital Center, Zagreb, Croatia
}

\begin{abstract}
SUMMARY - Postherpetic neuralgia (PHN) characterized by chronic neuropathic pain is a common complication of herpes zoster. We investigated the efficacy, safety and cost of treating refractory chronic neuropathic pain with 5\% topical lidocaine plaster (TLP) in a female patient attending pain unit at a small county hospital. An 80-year-old female diagnosed with PHN presented with severe left intercostal allodynia and hyperalgesia up to the root of the fourth to tenth thoracic dermatome. We administered the well established first- and second-line specific medications for PHN, but treatment regimens were not efficient. Then we introduced TLP and analyzed data from initial assessment and throughout follow up of 1313 days. The efficacy of treatment was based on pain severity that was assessed using the Short-Form McGill Pain Questionnaire and the related visual analog scale. In the last two years of observation, significant reduction was recorded in healthcare resource utilization (changes correlated with substantial reduction in direct cost (2012-2013: -425.90 €; and 2013-2014: $-1,435 €)$ and clinically relevant reduction in pain severity. No unusual side effects were observed. In conclusion, treatment of $\mathrm{PHN}$ with 5\% lidocaine plaster demonstrated efficacy in reducing pain severity and cost of medical care with a satisfactory safety profile. A starting point for future studies should be comparison of different treatment protocols and upgrading the knowledge, especially related to the cost of PHN treatment.
\end{abstract}

Key words: Postherpetic neuralgia; 5\% Topical lidocaine plaster; Allodynia; Elderly patient; Cost

\section{Introduction}

Herpes zoster is caused by reactivation of the varicella zoster virus in cranial nerves and spinal root ganglia $^{1,2}$. In some patients, pain does not resolve when the rash heals but continues for weeks, months or years; this persistent, neuropathic pain is termed postherpetic neuralgia $(\mathrm{PHN})^{3,4}$. The incidence is low among individuals younger than 40, ranging from 0.9 to 1.9 cases per 1000 patient-years, and increases with age to

Correspondence to: Assist. Prof. Narcis Hudorovic, MD, PhD, University Department of Surgery, Sestre milosrdnice University Hospital Center, Vinogradska c. 29, HR-10000 Zagreb, Croatia E-mail: narcis.hudorovic@zg.t-com.hr

Received July 7,2014, accepted October 20, 2014
9.4 cases per 1000 patient-years among individuals aged $\geq 80^{5-7}$. Anatomic PHN distribution follows the pattern of dermatomes affected by herpes zoster. Pain is characterized by burning, tingling or stinging, and is of a varying intensity sometimes described as unbearable. Hyperalgesia, hyperesthesia or allodynia may be associated ${ }^{7}$. The management of PHN is expensive, and patients often continue to suffer severe pain despite taking prescribed analgesics ${ }^{8}$. Recent systematic reviews of treatment options have concluded that tricyclic antidepressants are the most efficacious option; however, when patients become intolerant to prescribed medications and the potential for side effects is included in decision making, the administration of 5\% topical lidocaine plaster (TLP) is useful because of its 
localized efficacy and low incidence of systemic adverse reactions ${ }^{9,10}$.

This case report describes clinical presentation of PHN developed in an 80-year-old female patient with localized refractory neuropathic pain predominated by allodynia, for which TLP represented an alternative with benefits outweighing the risks. We analyzed the type of neuropathic pain observed and evaluated duration, efficacy and safety of treatment, costs and concomitant administration of co-analgesic and other antineuropathic drugs that may interfere with comorbidity.

\section{Case Report}

The 80-year-old female patient with small bullous lesions on the left sole of the foot was seen by a dermatologist, who made the diagnosis of herpes zoster in the healing phase of the lesions, and prescribed antibiotics and nonsteroidal anti-inflammatory drugs (NSAIDs). Treatment protocol was carried out according to recommendations issued by the Advisory Committee on Immunization Practices (ACIP). Pain severity was assessed using the Short-Form McGill Pain Questionnaire (SF-MPQ) and the related visual analog scale (VAS). Approval for its use was obtained from the authors (Immpact Group, Montreal, Canada). Medications were preceded by standardized instructions to patients, and each patient visit was performed in a quiet room with no distractions. The course of treatment, medications, side effects, VAS and costs are shown in Table 1.

The treatment was administered from November 2, 2010 to March 11, 2014 (1313 days). Key points of the treatment protocol were as follows: initial outpatient examination was performed at 6 weeks, on November 2 , 2010. After withdrawal of cutaneous efflorescences, the patient was referred to the Pain Control Unit, Dr Ivo Pedišić County Hospital in Sisak, Croatia. The pain was spreading throughout the left thoracic region with recurrent painful attacks. The patient reported strong burning sensation, tingling and painful touch. On physical evaluation, she presented pain provoked by typically nonpainful stimuli (allodynia) and hyperalgesia in the left thoracic region from the root of the fourth thoracic dermatome to the tenth thoracic dermatome. The treatment started with gabapentin (first week, $75 \mathrm{mg} /$ day; second week, $150 \mathrm{mg} /$ day; and third week, $300 \mathrm{mg} /$ day). Simultaneously, oral tricyclic anti- depressants (TCAs) were introduced at a dosage of 25 $\mathrm{mg} /$ day, along with long-acting form of tramadol in a dosage of $100 \mathrm{mg} /$ day and 5\% TLP. VAS was 8 and Present Pain Intensity (PPI) was 4.

On September 5, 2011, i.e. 337 days of treatment initiation, amitriptyline at a dose of $10 \mathrm{mg} /$ day in the evening and long-acting tramadol at the average daily dose of $300 \mathrm{mg} /$ day were added. VAS was $5-8$, with daily fluctuations, and PPI was 2-4. On June 24, 2011, 264 days of treatment introduction, gabapentin and amitriptyline were administered in the same average daily doses, while tramadol was reduced to $100 \mathrm{mg} /$ day. VAS was 5-8 and PPI was 2-4. On October 13, 2011, 413 days of treatment initiation, the average daily dose of gabapentin was reduced to $800 \mathrm{mg} /$ day. A combination of tramadol $(100 \mathrm{mg} /$ day $)$ and paracetamol $(900 \mathrm{mg} /$ day $)$ was introduced, resulting in reduced pain severity. VAS was 5-8 and PPI was 2-4. On April 5, 2012, 640 days of treatment initiation, amitriptyline was discontinued and carbamazepine introduced $(800 \mathrm{mg} /$ day). Tramadol was introduced in the form of drops ( $200 \mathrm{mg} / \mathrm{day}$, three times per week). The level of allodynia was reduced. Insomnia was not associated with pain intensity. On August 20, 2012, injections of diluted levobupivacaine with dexamethasone were administered in the paravertebral area from the $4^{\text {th }}$ to $10^{\text {th }}$ thoracic dermatome. Therapeutic effect was complemented with transcutaneous electrical nerve stimulation (TENS, $220 \mathrm{~Hz}, 110 \mu \mathrm{s}$ ). VAS was 5-8 and PPI was 2-4. On December 1,2013, 776 days of treatment introduction, opioid analgesic was discontinued due to side effects (diplopia, pruritus, alopecia, dry mouth and dizziness]. Carbamazepine (100 $\mathrm{mg} /$ day) and TLP were administered continuously. On November 10, 2013, 1181 days of initial examination, oral non-steroidal drug was introduced (400 mg/day). Mild burning sensation was present in the lower chest area at the $6^{\text {th }}$ to $9^{\text {th }}$ dermatome. During 2013, TLP was administered every 12 hours three days a week. VAS was 6 and PPI was 0. Final follow up examination was performed on March 11, 2014, 1313 days of the first examination. During the period from previous follow up examination, the patient had received one course of lidocaine with methylprednisolone (paravertebral block). All medications were discontinued. During the last two years of treatment, substantial reductions in direct costs (2012-2013: -470.90 €; and 20132014: $-1,417 €)$ were recorded, without adverse effects. 
Table 1. Treatment protocol for patient with postherpetic neuralgia

\begin{tabular}{|c|c|c|c|c|c|}
\hline & Year & & & & \\
\hline Treatment & 2010 & 2011 & 2012 & 2013 & 2014 \\
\hline TCAs & Amitriptyline & Amitriptyline & Carbamazepine & Nortriptyline & None \\
\hline Opioids & Tramadol & Tramadol & Tramadol & Tramadol & $\begin{array}{l}\text { Tramadol } \\
\text { (sporadically) }\end{array}$ \\
\hline $\begin{array}{l}\text { Antiepileptic } \\
\text { drugs }\end{array}$ & Gabapentin & Gabapentin & Gabapentin & Pregabalin & None \\
\hline $\begin{array}{l}\text { Topical } \\
\text { analgesics }\end{array}$ & TLP & $\begin{array}{l}\text { TLP } \\
\text { Paracetamol }\end{array}$ & TLP & $\begin{array}{l}\text { TLP } \\
\text { Carbamazepine }\end{array}$ & None \\
\hline NSAIDs & None & None & None & Ketoprofen & None \\
\hline VAS & $7-8$ & $5-8$ & $5-7$ & 6 & 1 \\
\hline Side effects & $\begin{array}{l}\text { Constipation; } \\
\text { drift on the fly; } \\
\text { alopecia; } \\
\text { dry mouth }\end{array}$ & $\begin{array}{l}\text { Pruritus, psychomotor } \\
\text { restlessness; insomnia }\end{array}$ & $\begin{array}{l}\text { Insomnia; } \\
\text { constipation; } \\
\text { ataxia; } \\
\text { alopecia }\end{array}$ & $\begin{array}{l}\text { Diplopia; } \\
\text { pruritus; } \\
\text { alopecia; dry } \\
\text { mouth; dizziness }\end{array}$ & None \\
\hline $\begin{array}{l}\text { Interventional } \\
\text { options }\end{array}$ & None & None & PVB; TENS & None & $\begin{array}{l}\text { Lidocaine } \\
+ \text { methyl- } \\
\text { prednisolone } \\
\text { (1x locally } \\
\text { administered } \\
\text { at left shoulder] }\end{array}$ \\
\hline Allodynia & $\begin{array}{l}\text { Pain like } \\
\text { electrical shock } \\
\text { at noon; } \\
\text { numbness along } \\
\text { affected area } \\
\text { during the night }\end{array}$ & $\begin{array}{l}\text { Strong burning sensation } \\
\text { at affected area appeared } \\
\text { at noon and lasted till } \\
4.00 \text { a.m., waking the } \\
\text { patient; pain like } \\
\text { electrical shock at noon, } \\
\text { numbness along affected } \\
\text { area during the night }\end{array}$ & $\begin{array}{l}\text { Annealing of } \\
\text { left lower } \\
\text { thoracic region }\end{array}$ & $\begin{array}{l}\text { Mild burning } \\
\text { sensation in the } \\
\text { lower left chest } \\
\text { area }\end{array}$ & None \\
\hline Cost (direct) & $\begin{array}{l}3,200.18 \text { HRK } \\
(421 €)\end{array}$ & $\begin{array}{l}12,800.77 \text { HRK } \\
(1,684 €)\end{array}$ & $\begin{array}{l}\text { 14,650.11 HRK } \\
(1,928 €)\end{array}$ & $\begin{array}{l}\text { 11,080.57 HRK } \\
(1,458 €)\end{array}$ & $\begin{array}{l}311.76 \text { HRK } \\
(41 €)\end{array}$ \\
\hline
\end{tabular}

TCAs = tricyclic antidepressants; TLP = 5\% topical lidocaine plaster; NSAIDs = nonsteroidal anti-inflammatory drugs; VAS = visual analog scale; PVB = paravertebral block; TENS = transcutaneous electrical nerve stimulation

\section{Discussion}

The efficacy of a combination of medications should be considered to achieve additional or even synergistic effects in the treatment of $\mathrm{PHN}^{10}$, as shown in this case report. The results recorded in the case presented demonstrate the efficacy and safety profile with very few local adverse reactions, as well as simplified treatment protocol and reduction in outpatient treatment costs and concomitant medication.

We present our results with the use of original treatment protocol for PHN. The main idea for creating a protocol for the treatment of $\mathrm{PHN}$ is the fact that topi- cal analgesics have lowest price among medicaments intended for PHN therapy, and that medical resources at a small county hospital are strictly limited, with a tendency to further reduction. Several limitations associated with this case report should be considered when interpreting the results. First, these results are based on a deterministic cost-effectiveness model and the final model must be a fully probabilistic model. Second, not included in this study, is the extensive sensitivity analysis around the base case deterministic cost-effectiveness estimates to fully explore the impact of uncertainty on our results. And finally, there is concern about comparability of the presented costs after switching to pregaba- 
lin treatment, in a real-life setting, and the level of comparability of the presented cost results with other published cost-effective analysis reports from a systematic literature review. Future studies in similar surroundings and with more parameters included should be undertaken to compare different treatment protocols and to improve the body of knowledge and thinking habits (costs) of medical professionals.

The results presented could be especially interesting for the treatment of PHN in small or/and middleincome countries where medical resources are strictly limited, with a tendency to further reduction. Future complementary prospective studies should be undertaken to demonstrate the favorable benefit-risk ratio in specific populations and to improve the body of knowledge on the use of TLP for PHN.

\section{References}

1. Pearce JM. Post herpetic neuralgia. J Neurol Neurosurg Psychiatry. 2005;76(4):572. doi: 10.1136/jnnp.2004.047381

2. Wu CL, Raja SN. An update on the treatment of postherpetic neuralgia. J Pain. 2008;9(1):19-30. doi: 10.1016/j.jpain.2007. 10.006

3. Kost RG, Straus SE. Postherpetic neuralgia: pathogenesis, treatment, and prevention. N Engl J Med. 1996;335:32-42. doi: 10.1056/NEJM199607043350107
4. Harpaz R, Ortega-Sanchez IR, Seward JF; Advisory Committee on Immunization Practices (ACIP), Centers for Disease Control and Prevention (CDC). Prevention of herpes zoster: recommendations of the Advisory Committee on Immunization Practices (ACIP). MMWR Recomm Rep. 2008;57 (RR-5):1-30.

5. Ruocco V, Sangiuliano S, Brunetti G, et al. Beyond zoster: sensory and immune changes in zoster-affected dermatomes: a review. Acta Derm Venereol. 2012;92:378-82. doi: 10.2340/ 00015555-1284

6. Insinga RP, Itzler RF, Pellissier JM, Saddier P, Nikas AA. The incidence of herpes zoster in a United States administrative database. J Gen Intern Med. 2005;20:748-53.

7. Navarro A, Saldaria MT, Perez C, Masramon X, Rejas J. Costs and health resources utilization following switching to pregabalin in individuals with gabapentin-refractory neuropathic pain: a post hoc analysis. Pain Pract. 2012;12:382-93.

8. Dworkin RH, Schmader KE. Treatment and prevention of postherpetic neuralgia. Clin Infect Dis. 2003;36(7):877-82. doi: $10.1086 / 368196$

9. Binder A, Bruxelle J, Rogers P, et al. Topical 5\% lidocaine (lignocaine) medicated plaster treatment for post-herpetic neuralgia: results of a double-blind, placebo-controlled, multinational efficacy and safety trial. Clin Drug Investig. 2009;29:393-408. doi: 10.2165/00044011-200929060-00003

10. Katz NP, Gammaitoni AR, Davis MW, Dworkin RH. Lidocaine patch $5 \%$ reduces pain intensity and interference with quality of life in patients with postherpetic neuralgia: an effectiveness trial. Pain Med. 2002;3:324-32. doi: 10.1046/ j.1526-4637.2002.02050.x

\title{
Sažetak \\ LIJEČENJE POSTHERPETIČNE NEURALGIJE UPORABOM 5\% LIDOKAINSKOG FLASTERA - ISKUSTVO ŽUPANIJSKE BOLNICE: PRIKAZ SLUČAJA
}

\author{
M. Kontic, V. Vičic-Hudorović i N. Hudorović
}

Pojava postherpetične neuralgije (PHN) jedna je od čestih komplikacija poslije herpes zostera. Opisujemo učinkovitost, sigurnost i troškove liječenja tvrdokorne kronične neuropatske boli lokalnom uporabom 5\%-tnog lidokainskog flastera u bolesnice liječene u maloj županijskoj bolnici. U 80-godišnje bolesnice s PHN dokazan je visok stupanj lijeve interkostalne alodinije i hiperalgezije od korijena četvrtog do desetog torakalnog dermatoma. Liječenje je započeto medikamentnom terapijom i to verificiranim lijekovima prvog i drugog reda za liječenje PHN, ali krajnji ishodi liječenja nisu bili učinkoviti. Stoga je u terapiju uveden lidokainski flaster te se opisuju simptomi od početka terapije i tijekom liječenja u trajanju od 1313 dana. Učinkovitost liječenja utvrđena je određivanjem stupnja bolnosti i to uporabom kratkih upitnika za procjenu stupnja bolnosti (McGill) i vizualne analogne ljestvice. U posljednje dvije godine liječenja zabilježeno je značajno smanjenje troškova liječenja (promjene u korelaciji sa značajnim smanjenjem izravnih troškova (2012.-2013.: -425,90 € i 2013.-2014.: -1435€) i klinički značajno smanjenje stupnja boli. U tijeku liječenja nije zabilježena pojava neželjenih učinaka. Zaključno, liječenje PHN uporabom 5\%-tnog lidokainskog flastera značajno smanjuje stupanj bolnosti, kao i ekonomske troškove provedene zdravstvene skrbi uz istodobno zadovoljavajući stupanj sigurnosti bolesnika. U budućnosti treba provesti istraživanja u svrhu usporedbe različitih protokola liječenja PHN, naročito radi utvrđivanja ukupnih troškova liječenja.

Ključne riječi: Postherpetična neuralgija; 5\%-tni lidokainski flaster; Alodinija; Bolesnikstarije životne dobi; Cijena 